\title{
A Novel SIX3 Mutation Segregates With Holoprosencephaly in a Large Family
}

\author{
Benjamin D. Solomon ${ }^{1}$, Felicitas Lacbawan ${ }^{1,2}$, Mahim Jain ${ }^{1}$, Sabina Domené ${ }^{1}$, Erich \\ Roessler $^{1}$, Cynthia Moore ${ }^{3}$, William B. Dobyns ${ }^{4}$, and Maximilian Muenke ${ }^{1,{ }^{*}}$ \\ ${ }^{1}$ Medical Genetics Branch, National Human Genome Research Institute, National Institutes of \\ Health, Bethesda, Maryland ${ }^{2}$ Department of Pathology, State University of New York Downstate \\ Medical Center, Brooklyn, New York ${ }^{3}$ Department of Medical and Molecular Genetics, Indiana \\ University School of Medicine, Indianapolis, Indiana ${ }^{4}$ Departments of Human Genetics, Neurology, \\ and Pediatrics, The University of Chicago, Chicago, Illinois
}

\begin{abstract}
Holoprosencephaly is the most common structural malformation of the forebrain in humans and has a complex etiology including chromosomal aberrations, single gene mutations and environmental components. Here we present the pertinent clinical findings among members of an unusually large kindred ascertained over 15 years ago following the evaluation and subsequent genetic work-up of a female infant with congenital anomalies. A genome-wide scan and linkage analysis showed only suggestive evidence of linkage to markers on chromosome 2 among the most likely of several pedigree interpretations. We now report that a novel missense mutation in the SIX3 holoprosencephaly gene is the likely cause in this family. Molecular genetic analysis and/or clinical characterization now show that at least 15 members of this family are presumed SIX 3 mutation gene carriers, with clinical manifestations ranging from phenotypically normal adults (non-penetrance) to alobar holoprosencephaly incompatible with postnatal life. This particular family represents a seminal example of the variable manifestations of gene mutations in holoprosencephaly and difficulties encountered in their elucidation.
\end{abstract}

\section{Keywords}

holoprosencephaly; HPE; SIX3

\section{INTRODUCTION}

Holoprosencephaly (HPE) occurs due to incomplete midline cleavage of the developing brain during the third and fourth weeks of gestation and is the most common structural malformation involving the human forebrain. HPE affects about 1 in 250 gestations, but this falls to only about 1 in 10,000 live births [Matsunaga and Shiota, 1977; Leoncini et al., 2008]. Three classical recognizable degrees of severity, defined by the extent of brain malformation, have been described: alobar, semilobar, and (frontal) lobar HPE [Muenke and Beachy, 2000; Cohen, 2006]. In addition, a posterior form of lobar HPE designated middle interhemispheric variant (MIHV or "syntelencephaly") has also been recognized [Barkovich and Quint, 1993]. Clinical

\footnotetext{
*Correspondence to: Maximilian Muenke, M.D., Medical Genetics Branch, National Human Genome Research Institute, National Institutes of Health, Building 35, Room 1B-203, Bethesda, MD 20892. mamuenke@ mail.nih.gov.

$\dagger$ This article is a US Government work and, as such, is in the public domain in the United States of America.
} 
manifestations typically include characteristic craniofacial anomalies, developmental disabilities, pituitary insufficiency, and seizures. Craniofacial findings tend to correlate with the severity of brain anomalies. Individuals at the severe end of the spectrum may manifest severe microcephaly, a single eye (cyclopia), anophthalmia or microophthalmia, a mound of tissue located just above a fused eye or two very closely spaced eyes designated a proboscis, absent nasal septum, and midline or bilateral cleft lip and palate. At the less severe end of the spectrum, sometimes termed an HPE "microform," patients may have microcephaly, hypotelorism, and single maxillary central incisor without the structural brain changes of HPE. Severely affected patients do not typically survive the neonatal period. Less severely affected individuals may have a normal lifespan [Cohen, 2006; Dubourg et al., 2007].

HPE can be caused by single gene mutations, although mutations in the four most common HPE-associated genes account for less than 25\% of patients with HPE [Lazaro et al., 2004; Muenke, unpublished data]. Sonic hedgehog $(\mathrm{SHH})$ was the first causal gene discovered and is still the only HPE locus identified by linkage analysis [Muenke et al., 1994; Roessler et al., 1996]. Since this promising beginning, linkage analysis has been less successful as a gene discovery method, and further elucidation of HPE-associated genes has largely proceeded through testing for mutations in genes in known $\mathrm{SHH}$-related pathways and/or in regions identified in individuals with HPE and chromosomal anomalies [Brown et al., 1998; Gripp et al., 2000; Ming et al., 2002]. For example, GLI2 was known to be one member of a family of transcriptional mediators for $\mathrm{SHH}$, and examination of human pedigrees revealed HPEsegregating mutations in GLI2. Families segregating mutations of GLI2 or other HPE causal genes highlight the markedly variable expressivity observed in patients with HPE-segregating mutations, suggesting additional environmental or genetic influences acting as modifying factors [Roessler et al., 2003]. In other words, a mutation in a gene such as GLI2 is necessary but not sufficient for HPE, and other genetic or environmental factors must be present for complete phenotypic manifestation [Ming and Muenke, 2002].

SIX3 was identified as an HPE candidate gene in individuals with HPE and structural rearrangements of chromosome 2p21 [Schell et al., 1996; Wallis et al., 1999]. Heterozygous mutations in SIX3 are now known in over 120 individuals representing over 60 different kindreds with HPE, with clinical findings again demonstrating incomplete penetrance and highly variable expressivity [Wallis et al., 1999; Nanni et al., 2000; Pasquier et al., 2000, 2005; Dubourg et al., 2004; Lazaro et al., 2004; Ribeiro et al., 2006; Bendavid et al., 2006a,b; El-Jaick et al., 2007; Domené et al., 2008; Muenke, unpublished data].

The vertebrate Six genes encode a family of transcription factors orthologous to the Drosophila sine oculis ("without eyes") gene that functions in the developing fly's visual system. Vertebrate Six 3 is involved in midline forebrain and eye formation in several organisms [Oliver et al., 1995; Kobayashi et al., 1998; Gestri et al., 2005]. Known biological properties of vertebrate Six 3 include transcriptional repression of BMP, Wnt and Nodal targets through complex(s) formed with Groucho, influence over cellular fate in the developing forebrain through interactions with Geminin, activation of lens specification during eye formation, and, importantly, regulation of SHH in the ventral forebrain [Kobayashi et al., 2001; Lagutin et al., 2003; Del Bene et al., 2004; Liu et al., 2006; Inbal et al., 2007; Geng et al., 2008]. Proteins encoded by the Six genes typically contain a DNA-binding homeobox domain and an upstream SIX domain that can recruit factors to accomplish transcriptional activation or repression [Kawakami et al., 1996; Granadino et al., 1999].

Here we present a large kindred initially ascertained due to birth of an infant with alobar HPE. Subsequent study of her family showed that at least 15 members in 5 generations segregate a mutation in SIX3. 


\section{MATERIALS AND METHODS}

Blood samples were sent to the Muenke laboratory for analysis after obtaining appropriate consent. Mutation detection was performed by PCR amplification of all exons, single-strand conformational polymorphism (SSCP), and denaturing high performance liquid chromatography (dHPLC) screening, and bidirectional sequencing as described previously [Wallis et al., 1999; Domené et al., 2008]. Direct sequencing of the proposita's SHH gene was performed, by techniques previously described [Roessler et al., 1996]. After mutation identification, a retrospective genome-wide scan was performed using microsatellite markers genotyped by DeCODE genetics (1.5 cM average spacing, 2000 markers) under contract agreement. Mendelian errors were detected using PEDCHECK and were removed from analysis [O'Connell and Weeks, 1998]. Parametric and non-parametric linkage analyses were performed using GENEHUNTER-PLUS [Kruglyak et al., 1996; Kong and Cox, 1997]. Given the evidence of reduced penetrance and potential misclassification of phenocopies as HPE micoforms, parametric linkage analysis was run with autosomal dominant penetrance parameters of 0.10 for genotype aa and 0.80 for genotypes Aa or AA; an allele frequency of the disease causing mutation was set at 0.001 for all parametric analyses. For suggestive regions of linkage, haplotyping was performed using MERLIN's best function [Abecasis et al., 2001]. Haplotypes were evaluated using HAPLOPAINTER to define minimal critical genomic intervals by examining recombination events [Thiele and Nürnberg, 2005].

\section{RESULTS}

\section{Family Description}

The family (Fig. 1 and Fig 2) was ascertained at Indiana University Hospital over 15 years ago (by C.M. and W.B.D.) following evaluation of a 1-day-old girl (IV.19) born at term with congenital anomalies including macrocephaly, severe hypotelorism, a short nose with upturned nares, a hypoplastic philtrum consisting of a thin vertical groove, low-set ears, a slightly small jaw, and normal palate. Her fingers were overlapping (finger 3 overlapping 4 bilaterally) with slight contractures and deep but otherwise normal palmar creases. Cranial CT revealed alobar HPE and hydrocephalus (Fig. 2). Interestingly, DNA from this child and her family comprised one of the first complete family sets sent to the Muenke lab in 1990 for research testing. This sample was eventually screened for mutations in SHH, ZIC2, SIX3, and TGIF by SSCP analysis. We now reflect that the apparent lack of band-shift with $S I X 3$ specific primers represents our first obvious instance of false negative screening results [Muenke, unpublished data].

Subsequently, over 20 members of the patient's extended family were examined by the authors, largely by W.B.D. (Fig. 1 and Table I for details). Findings consistent with full HPE occurred in three individuals including the proposita. Six other children died in early infancy of unknown causes. At least nine individuals had a subtle facial microform consisting of a sharp angular nose with either frank hypotelorism or a mildly narrow nasal bridge (Fig. 2). One young man (IV.4) had bilateral microphthalmia, microcornea, and coloboma of the iris, choroid and retina with reportedly normal intelligence. We were unable to perform an examination or review photographs on this individual. One girl (IV.20) had isolated mental retardation (her IQ was about 50), microcephaly, a normal facial appearance, and a normal brain MRI. We thought that she had an HPE microform for many years, but she was later found not to carry the SIX3 mutation.

\section{Genetic Testing}

The original samples were ascertained over 15 years ago, prior to identification of HPE-causing genes. The initial linkage analysis was done using data from 21 individuals (including 
individual IV.20) and modeled for reduced penetrance and phenocopies, but the results were inconclusive. DNA samples from this family were later tested by SSCP as candidate HPE genes were identified through other studies. Though the proposita's sample did not initially reveal positive findings, dHPLC on her maternal uncle (III.5) ultimately showed a positive finding in SIX3. Direct sequencing detected a missense mutation in the SIX domain of SIX3: c.339G>T, resulting in p.W113C. This mutation results in an almost complete loss of function, as demonstrated by functional studies using a zebrafish model [Domené et al., 2008]. Sequencing of SIX3 was performed on 8 individuals, 6 of whom were found to have the mutation: the proposita (IV.19), her mother (III.7), two maternal aunts (III.1, III.8), a maternal uncle (III.5), and her maternal grandmother (II.2). Two individuals tested negative for SIX3 mutations: a maternal uncle (III.11) and his daughter, a maternal first cousin (IV.20). Finally, because of recent work showing direct Six3-Shh interactions [Geng et al., 2008], SHH sequencing was performed in the proposita and did not show any sequence variations.

When a retrospective linkage analysis was performed with the information garnered through direct sequencing, three signals overlapped or neighbored previously described genes for HPE: SIX3 on chromosome $2 \mathrm{p}(\operatorname{Lod}=1.12, \mathrm{NPL}=2.57), \mathrm{PTCH} 1$ on chromosome $9 \mathrm{q}(\mathrm{NPL}=2.36)$ and $T G I F$ on chromosome $18 \mathrm{p}(\mathrm{NPL}=2.57)$. However, none of these signals reached the level of statistical significance. Haplotype analysis provided further evidence against both $\mathrm{PTCH}$, as one affected individual did not share the linked haplotype, and $T G I F$ due to a recombination event $300 \mathrm{~Kb}$ upstream of the gene.

Haplotype analysis in the SIX3 region using available DNA samples demonstrated that 9 individuals had a shared haplotype, and one individual in generation I must have carried the mutation as multiple offspring were affected. Two key crossover events in individuals III.5 (centromeric) and III.8 (telomeric) identified a SIX3 mutation-containing haplotype delimited by markers D2S2328 and D2S2294. This analysis identified 3 individuals in addition to those found by direct sequencing who co-segregated the haplotype containing the mutated SIX 3 gene. Direct mutation testing was not performed on these individuals, as samples were no longer available. One of them, a maternal first cousin (IV.14), had a normal phenotype, while two, a maternal half-sister (IV.15) and maternal great uncle (II.5), had an HPE microform consisting of a sharply angular nose without apparent hypotelorism.

\section{DISCUSSION}

Here we report the largest single kindred with the most confirmed cases of a molecularlydefined SIX3 mutation. There is evidence that nine individuals in four generations carry the mutation, as shown by either direct sequencing or the presence of the SIX 3 mutation-specific haplotype. At least an additional 4 individuals had clinical signs of HPE spectrum, and 2 individuals were presumed carriers, yielding presumptive positive findings in 15 individuals among 5 generations. It is possible that fewer individuals had the mutation. For example, individual II.5 might carry the same haplotype as those with the mutation, but not the mutation itself, and individual III.27 could have HPE due to a reason other than the mutation in SIX3. While a common mutation in at least these 15 individuals is the simplest explanation, it cannot be assumed that Occam's razor provides the only explanation.

Study of this kindred recalls lessons learned in previous studies of HPE and other complex traits. First, this pedigree demonstrates the difficulties in the use of linkage analysis as a tool to discover disease-causing genes. Phenocopies are one complicating factor. Here, initial linkage analysis including the apparent phenocopy (IV.20) and her parent (III.11) did not demonstrate any meaningful linkage to the SIX3 locus. Even when direct mutation testing demonstrated that the phenocopy did not possess the mutation, repeat linkage analysis did not achieve statistical significance at the SIX3 locus. 
Second, this pedigree demonstrates well the incomplete penetrance and variable expressivity seen in other kindreds with HPE. As described according to the "multiple hit" theory [Ming and Muenke, 2002] other genetic and/or environmental factors likely affect phenotypic severity. In fact, the phenocopy described here (IV.20) may have been affected by these "modifying" factors, but may not herself have possessed the mutation in SIX3. Despite the recent elucidation of the potential for direct Six3-Shh genetic interactions in animals, there are no known cases of HPE in humans due to simultaneous mutations in SIX3 and SHH. Perhaps exonic coding mutations in $\mathrm{SHH}$ are not found simultaneously with similar changes in SIX3, but $\mathrm{SHH}$ regulatory changes not routinely tested in CLIA laboratories may co-occur.

Third, this kindred illustrates the challenges of genetic counseling in cases such as these. Despite the fact that this sequence change was shown to be a significant loss-of-function mutation, the presence of the mutation in SIX3 was seen in both unaffected individuals and in individuals with severe HPE. In these circumstances, genetics professionals must be aware of this range of possibilities, and should attempt to incorporate this understanding both in the interpretation of test results and in making prognoses.

Finally, clinical examination of individuals with the SIX3 mutation who were considered to possess the HPE microform often had a sharply angular nose (described as "knifelike" by one clinician) without true hypotelorism or microcephaly. The correlation of this phenotype with the presence of the mutation was more obvious in retrospect, and highlights the fact that genetic disorders may manifest in ways not exactly as traditionally described. Along these lines, 15 years passed between the initial genetic consultation on the proposita and the elucidation of the molecular cause. This extended diagnostic period demonstrates the importance of perseverance despite initially negative studies, including applying new technology and testing newly discovered genes.

\section{ACKNOWLEDGEMENTS}

The authors would like to thank Julia Fekecs for her help with illustrations and would like to extend deep gratitude to the family described here. This work was supported by the Division of Intramural Research, National Human Genome Research Institute, National Institutes of Health.

\section{REFERENCES}

Abecasis GR, Cardon LR, Cookson WO, Sham PC, Cherny SS. Association analysis in a variance components framework. Genet Epidemiol 2001;21:S341-S346. [PubMed: 11793695]

Barkovich AJ, Quint DJ. Middle interhemispheric fusion: Anunusual variant of holoprosencephaly. Am J Neuroradiol 1993;14:431-440. [PubMed: 8456724]

Bendavid C, Dubourg C, Gicquel I, Pasquier L, Saugier-Veber P, Durou MR, Jaillard S, Frebourg T, Haddad BR, Henry C, Odent S, David V. Molecular evaluation of foetuses with holoprosencephaly shows high incidence of microdeletions in the HPE genes. Hum Genet 2006a;119:1-8. [PubMed: 16323008]

Bendavid C, Haddad BR, Griffin A, Huizing M, Dubourg C, Gicquel I, Cavalli LR, Pasquier L, Shanske AL, Long R, Ouspenskaia M, Odent S, Lacbawan F, David V, Muenke M. Multicolour FISH and quantitative PCR can detect submicroscopic deletions in holoprosencephaly patients with a normal karyotype. J Med Genet 2006b;43:496-500. [PubMed: 16199538]

Brown SA, Warburton D, Brown LY, Yu CY, Roeder ER, Stengel-Rutkowski S, Hennekam RC, Muenke M. Holoprosencephaly due to mutations in ZIC2, a homologue of Drosophila odd-paired. Nat Genet 1998;20:180-183. [PubMed: 9771712]

Cohen MM Jr. Holoprosencephaly: Clinical, anatomic, and molecular dimensions. Birth Defects Res A Clin Mol Teratol 2006;76:658-673. [PubMed: 17001700]

Del Bene F, Tessmar-Raible K, Wittbrodt J. Direct interaction of geminin and Six3 in eye development. Nature 2004;427:745-749. [PubMed: 14973488] 
Domené S, Roessler E, El-Jaick K, Boorech J, Vélez JI, Bale S, Lacbawan F, Muenke M, Feldman B. Mutations in the human SIX3 gene in holoprosencephaly are loss-of-function. HumMol Genet 2008;17:3919-3928.

Dubourg C, Lazaro L, Pasquier L, Bendavid C, Blayau M, Le Duff F, Durou MR, Odent S, David V. Molecular screening of $S H H, Z I C 2$, SIX3, and TGIF genes in patients with features of holoprosencephaly spectrum: Mutation review and genotype-phenotype correlations. Hum Mutat 2004;24:43-51. [PubMed: 15221788]

Dubourg C, Bendavid C, Pasquier L, Henry C, Odent S, David V. Holoprosencephaly. Orphanet J Rare Dis 2007;2:8. [PubMed: 17274816]

El-Jaick KB, Fonseca RF, Moreira MA, Ribeiro MG, Bolognese AM, Dias SO, Pereira ET, Castilla EE, Orioli IM. Single median maxillary central incisor: New data and mutation review. Birth Defects Res A Clin Mol Teratol 2007;79:573-580. [PubMed: 17584896]

Geng X, Speirs C, Lagutin O, Inbal A, Liu W, Solnica-Krezel L, Jeong Y, Epstein DJ, Oliver G. Haploinsufficiency of Six 3 fails to activate Sonic hedgehog expression in the ventral forebrain and causes holoprosencephaly. Dev Cell 2008;15:236-247. [PubMed: 18694563]

Gestri G, Carl M, Appolloni I, Wilson SW, Barsacchi G, Andreazzoli M. Six3 functions in anterior neural plate specification by promoting cell proliferation and inhibiting Bmp4 expression. Development 2005;132:2401-2413. [PubMed: 15843413]

Granadino B, Gallardo ME, Lopez-Rios J, Sanz R, Ramos C, Ayuso C, Bovolenta P, Rodriguez de Cordoba S. Genomic cloning, structure, expression pattern, and chromosomal location of the human SIX3 gene. Genomics 1999;55:100-105. [PubMed: 9889003]

Gripp KW, Wotton D, Edwards MC, Roessler E, Ades L, Meinecke P, Richieri-Costa A, Zackai EH, Massagué J, Muenke M, Elledge SJ. Mutations in TGIF cause holoprosencephaly and link NODAL signaling to human neural axis determination. Nat Genet 2000;25:205-208. [PubMed: 10835638]

Inbal A, Kim SH, Shin J, Solnica-Krezel L. Six3 represses nodal activity to establish early brain asymmetry in zebrafish. Neuron 2007;55:407-415. [PubMed: 17678854]

Kawakami K, Ohto H, Takizawa T, Saito T. Identification and expression of six family genes in mouse retina. FEBS Lett 1996;393:259-263. [PubMed: 8814301]

Kobayashi M, Toyama R, Takeda H, Dawid IB, Kawakami K. Overexpression of the forebrain-specific homeobox gene Six3 induces rostral forebrain enlargement in zebrafish. Development 1998;125:2973-2982. [PubMed: 9655819]

Kobayashi M, Nishikawa K, Suzuki T, Yamamoto M. The homeobox protein Six3 interacts with the Groucho corepressor and acts as a transcriptional repressor in eye and forebrain formation. Dev Biol 2001;232:315-326. [PubMed: 11401394]

Kong A, Cox NJ. Allele-sharing models: LOD scores and accurate linkage tests. Am J Hum Genet 1997;61:1179-1188. [PubMed: 9345087]

Kruglyak L, Daly MJ, Reeve-Daly MP, Lander ES. Parametric and nonparametric linkage analysis: A unified multipoint approach. Am J Hum Genet 1996;58:1347-1363. [PubMed: 8651312]

Lagutin OV, Zhu CC, Kobayashi D, Topczewski J, Shimamura K, Puelles L, Russell HR, McKinnon PJ, Solnica-Krezel L, Oliver G. Six3 repression of Wnt signaling in the anterior neuroectoderm is essential for vertebrate forebrain development. Genes Dev 2003;17:368-379. [PubMed: 12569128]

Lazaro L, Dubourg C, Pasquier L, Le Duff F, Blayau M, Durou MR, de la Pintiére AT, Aguilella C, David V, Odent S. Phenotypic and molecular variability of the holoprosencephalic spectrum. Am J Med Genet Part A 2004;129A:21-24. [PubMed: 15266610]

Leoncini E, Baranello G, Orioli IM, Annerén G, Bakker M, Bianchi F, Bower C, Canfield MA, Castilla EE, Cocchi G, Correa A, De Vigan C, Doray B, Feldkamp ML, Gatt M, Irgens LM, Lowry RB, Maraschini A, Mc Donnell R, Morgan M, Mutchinick O, Poetzsch S, Riley M, Ritvanen A, Gnansia ER, Scarano G, Sipek A, Tenconi R, Mastroiacovo P. Frequency of holoprosencephaly in the International Clearinghouse Birth Defects Surveillance Systems: Searching for population variations. Birth Defects Res A Clin Mol Teratol 2008;82:585-591. [PubMed: 18566978]

Liu W, Lagutin OV, Mende M, Streit A, Oliver G. Six3 activation of Pax6 expression is essential for mammalian lens induction and specification. EMBO J 2006;25:5383-5395. [PubMed: 17066077]

Matsunaga E, Shiota K. Holoprosencephaly in human embryos: Epidemiologic studies of 150 cases. Teratology 1977;16:261-272. [PubMed: 594909] 
Ming JE, Muenke M. Multiple hits during early embryonic development: Digenic diseases and holoprosencephaly. Am J Hum Genet 2002;71:1017-1032. [PubMed: 12395298]

Ming JE, Kaupas ME, Roessler E, Brunner HG, Golabi M, Tekin M, Stratton RF, Sujansky E, Bale SJ, Muenke M. Mutations in PATCHED-1, the receptor for SONIC HEDGEHOG, are associated with holoprosencephaly. Hum Genet 2002;110:297-301. [PubMed: 11941477]

Muenke M, Beachy PA. Genetics of ventral forebrain development and holoprosencephaly. Curr Opin Genet Dev 2000;10:262-269. [PubMed: 10826992]

Muenke M, Gurrieri F, Bay C, Yi DH, Collins AL, Johnson VP, Hennekam RC, Schaefer GB, Weik L, Lubinsky MS. Linkage of a human brain malformation, familial holoprosencephaly, to chromosome 7 and evidence for genetic heterogeneity. Proc Natl Acad Sci USA 1994;91:8102-8106. [PubMed: 8058764]

Nanni L, Croen LA, Lammer EJ, Muenke M. Holoprosencephaly: Molecular study of a California population. Am J Med Genet Part A 2000;90:315-319.

O'Connell JR, Weeks DE. PedCheck: A program for identification of genotype incompatibilities in linkage analysis. Am J Hum Genet 1998;63:259-266. [PubMed: 9634505]

Oliver G, Mailhos A, Wehr R, Copeland NG, Jenkins NA, Gruss P. Six3, a murine homologue of the sine oculis gene, demarcates the most anterior border of the developing neural plate and is expressed during eye development. Development 1995;121:4045-4055. [PubMed: 8575305]

Pasquier L, Dubourg C, Blayau M, Lazaro L, Le Marec B, David V, Odent S. A new mutation in the sixdomain of SIX3 gene causes holoprosencephaly. Eur J Hum Genet 2000;8:797-800. [PubMed: 11039582]

Pasquier L, Dubourg C, Gonzales M, Lazaro L, David V, Odent S, Encha-Razavi F. First occurrence of aprosencephaly/atelencephaly and holoprosencephaly in a family with a SIX3 gene mutation and phenotype/genotype correlation in our series of SIX3 mutations. J Med Genet 2005;42:e4. [PubMed: 15635066]

Ribeiro LA, El-Jaick KB, Muenke M, Richieri-Costa A. SIX3 mutations with holoprosencephaly. AmJ Med Genet Part A 2006;140A:2577-2583. [PubMed: 17001667]

Roessler E, Belloni E, Gaudenz K, Jay P, Berta P, Scherer SW, Tsui LC, Muenke M. Mutations in the human Sonic Hedgehog gene cause holoprosencephaly. Nat Genet 1996;14:357-360. [PubMed: 8896572]

Roessler E, Du YZ, Mullor JL, Casas E, Allen WP, Gillessen-Kaesbach G, Roeder ER, Ming JE, Ruiz i Altaba A, Muenke M. Loss-of function mutations in the human GLI2 gene are associated with pituitary anomalies and holoprosencephaly-like features. Proc Natl Acad Sci USA 2003;100:1342413429. [PubMed: 14581620]

Schell U, Wienberg J, Köhler A, Bray-Ward P, Ward DE, Wilson WG, Allen WP, Lebel RR, Sawyer JR, Campbell PL, Aughton DJ, Punnett HH, Lammer EJ, Kao FT, Ward DC, Muenke M. Molecular characterization of breakpoints in patients with holoprosencephaly and definition of the HPE2 critical region 2p21. Hum Mol Genet 1996;5:223-229. [PubMed: 8824878]

Thiele H, Nürnberg P. HaploPainter: A tool for drawing pedigrees with complex haplotypes. Bioinformatics 2005;21:1730-1732. [PubMed: 15377505]

Wallis DE, Roessler E, Hehr U, Nanni L, Wiltshire T, Richieri-Costa A, Gillessen-Kaesbach G, Zackai $\mathrm{EH}$, Rommens J, Muenke M. Mutations in the homeodomain of the human SIX3 gene cause holoprosencephaly. Nat Genet 1999;22:196-198. [PubMed: 10369266] 


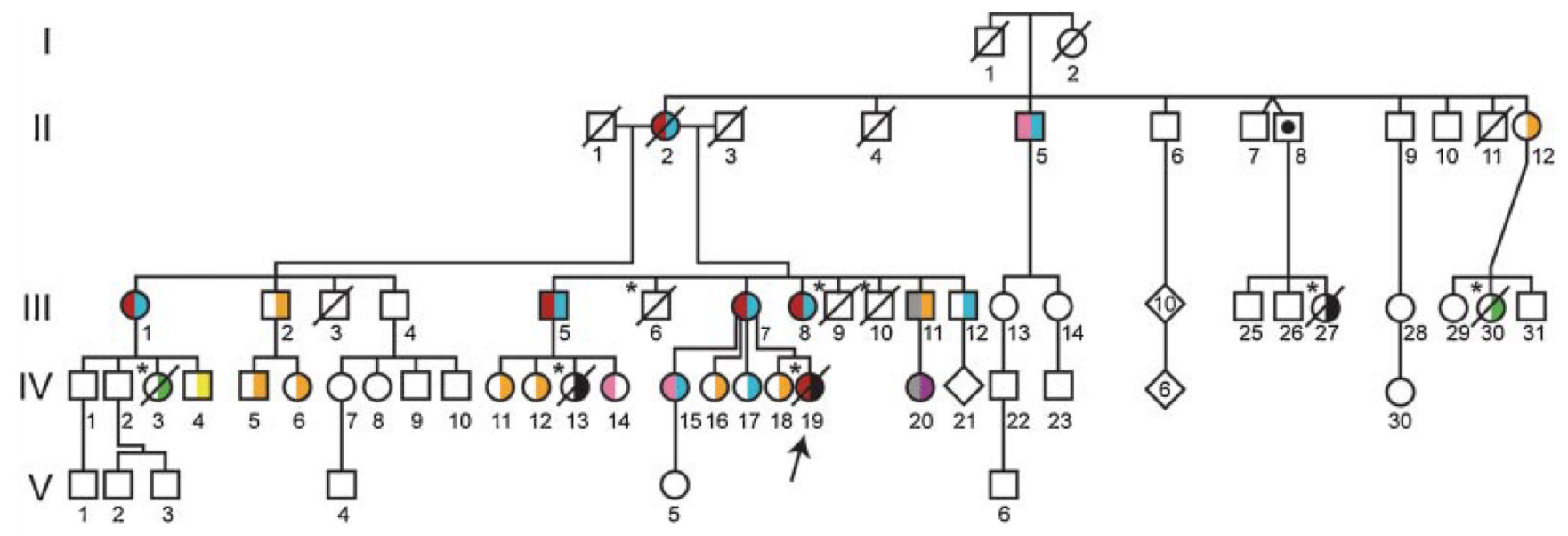

DI SIX3 mutation positive

\section{$\square \bigcirc$ Microphthalmia}

$\square \bigcirc$ Segregating mutation-carrying haplotype

口0 Normal sequence

प(1) Holoprosencephaly

Other malformations

口(1) HPE Microform

1. Mental retardation only

* Neonatal death

Figure 1.

Pedigree of family. 

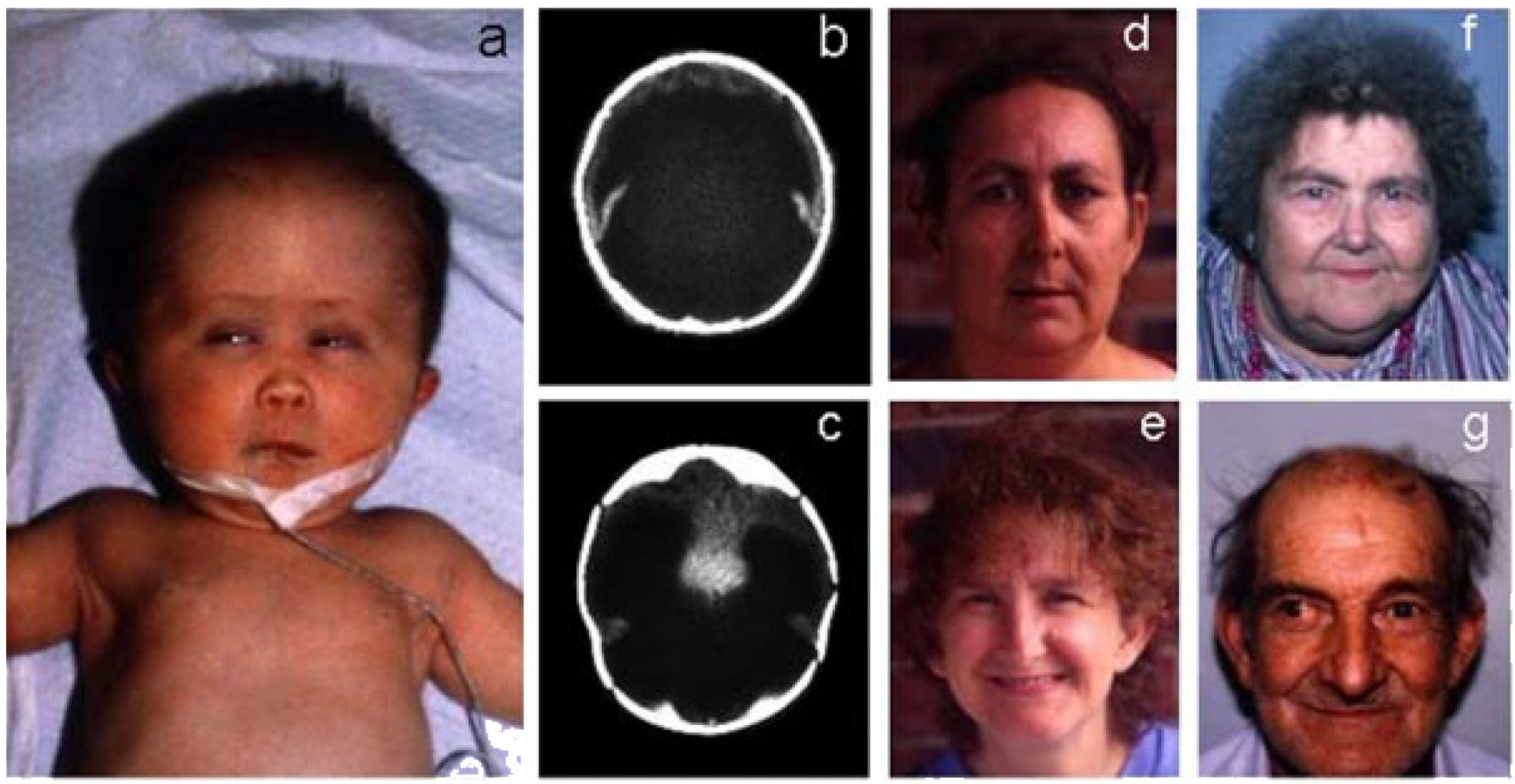

Figure 2.

a: Proposita (IV.19) with macrocephaly, hypotelorism, hypoplastic philtrum, and low-set ears; (b,c) head CT showing alobar HPE and hydrocephalus; (d) mother (III.7); (e) aunt (III.8); (f) grandmother (II.2); (g) great-uncle (II.5). All individuals had evidence for the presence of the SIX3 mutation. The proposita's relatives show various signs of microform HPE, with varying degrees of microcephaly, hypotelorism, and thin nasal bridges. 


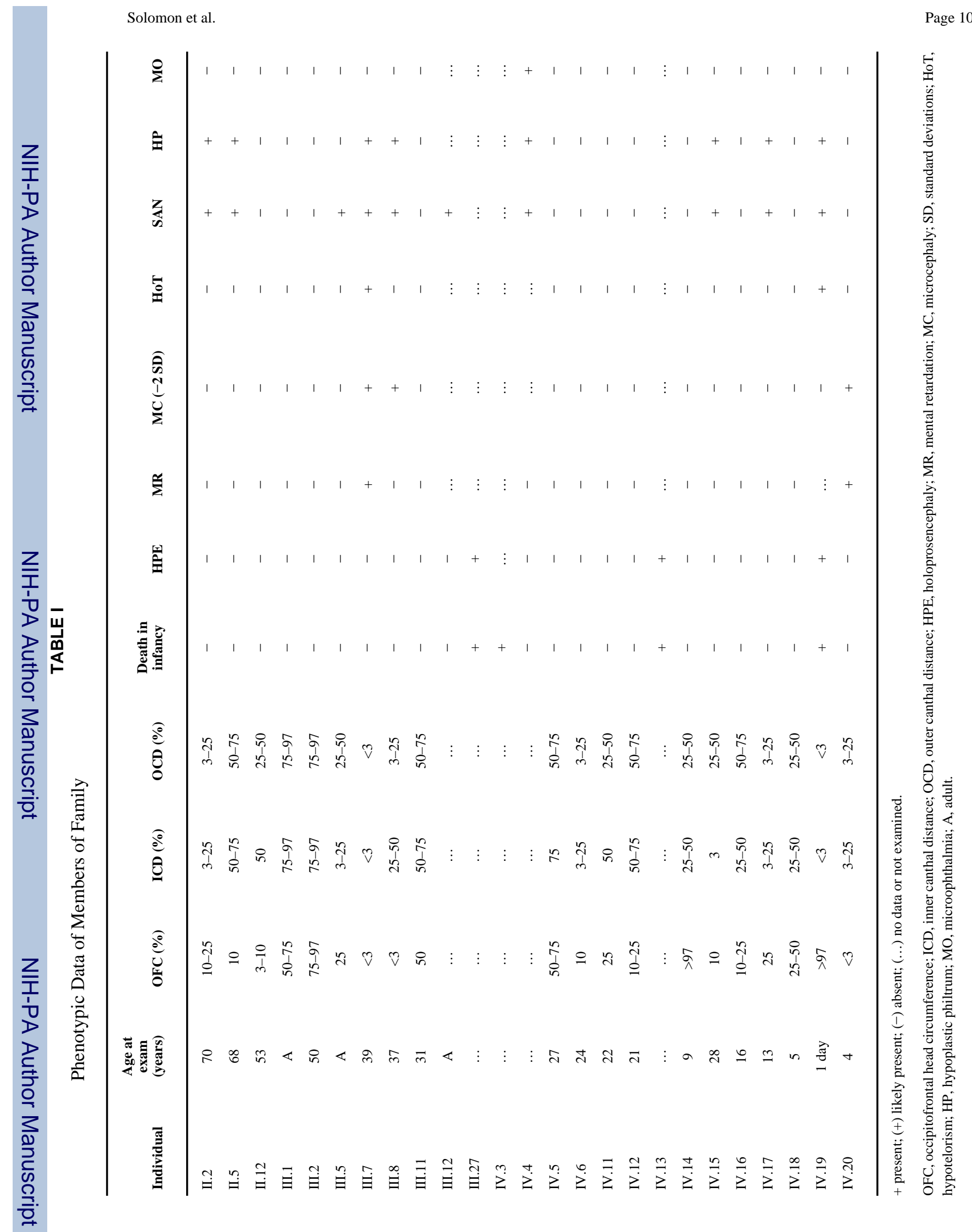

Am J Med Genet A. Author manuscript; available in PMC 2009 September 4. 